\title{
Can a Leader's Positive Evaluation Improve Occupational Satisfaction of Employees? — Based on the Empirical Investigation of a Real Estate Enterprise G Province Branch
}

\author{
Chengmeng Zhang ${ }^{1,2}$, Meiqing Leng ${ }^{2}$, Shuting $\mathrm{Xu}^{1}$ \\ ${ }^{1}$ College of Management, Shenzhen University \\ ${ }^{2}$ Institute for Disability and Philanthropy, Shenzhen University \\ Correspondence: Chengmeng Zhang, Institute for Disability and Philanthropy, Office 318 in Tech-building, \\ Shenzhen University, No. 3688, Nanhai Avenue, Nanshan District, Shenzhen, Guangdong, China.
}

Received: April 29, 2019

doi:10.5539/ibr.v12n11p57

\author{
Accepted: June 3, 2019 \\ Online Published: October 21, 2019 \\ URL: https://doi.org/10.5539/ibr.v12n11p57
}

\begin{abstract}
Employees are the creators of corporate benefits. The level of occupational satisfaction is directly related to the performance of employees and the survival and development of enterprises. Through the analysis of the questionnaire data of 538 employees of the B group G province branch, it is found that the employee's "self-efficacy" is the most affecting the occupational satisfaction of the real estate employees if and only if all the variables work together on the employee occupational satisfaction. There is no significant correlation between "employee and leadership and co-worker relationship", "leading positive evaluation of employees" and occupational satisfaction. The results show that as a new type of enterprise entity, real estate enterprises should pay attention to the incentives for employee performance, continuously promote the management system to be scientific and reasonable, and achieve the organizational recognition of employees and the improvement of occupational satisfaction.
\end{abstract}

Keywords: occupational satisfaction, social capital, self-efficacy, organizational identity, trust relationship

\section{Introduction}

Employees are the strategic resources and valuable human capital of the company. Nowadays, more and more employees are paying attention to their feelings at work. Employees who like and love their work can usually enjoy and devote to their work, and these employees can reduce recruitment and training costs for the companies. The occupational satisfaction of employees is part of human resource management. The satisfaction of employees in enterprises has always been the subject of many scholars. In 1935, the scholar Hoppock published the article "Occupational Satisfaction", which defined the concept of "occupational satisfaction", that is, the subjective satisfaction of the workers' work, including physical and psychological attitudes, emotional reactions, employees with higher occupational satisfaction will be more disciplined, with better job performance and professional ethics (Fathoni, 2006) .Ni (2007) found that when employees are satisfied, they are more likely to establish long-term partnerships in four widely studied employee relationship indicators (ie trust, control, commitment, and satisfaction) .Leindra and Sugiono (2014) stated that employees who are satisfied with their work will work more effectively and contribute to the company's development and goals. High-performance work has a significant positive correlation with occupational satisfaction. In the enterprise, the higher the performance of the employees, the more employees can get, which can effectively promote the employees' satisfaction with the work and the company. The high-performance work system has a significant positive effect on the organizational identity of the employees (Wang, 2018). In recent years, the real estate industry has attracted a large number of outstanding employees with "high salary" and "big platform". This kind of talent-intensive phenomenon should be worthy of in-depth study. Exploring the factors affecting the career satisfaction of the employees behind the welfare and high treatment can better understand the human resource management strategy under the high-performance background of real estate enterprises, and can also provide reference for the organizational transformation of new-type commercial entities such as real estate enterprises.

\section{Literature Review and Hypotheses}

The relationship between leadership and employees, traditional research is concentrated in the scope of human 
resource management. However, human resource management is a working relationship constructed in the occupational division of labor, while neglecting the tendency of action and value pursuit among individual roles. This article mainly uses social capital theory to analyze employees as the object of analysis, aiming to explore the relationship between employees' social capital and employee occupational satisfaction.

Social capital mainly studies how people use social capital to improve their economic status and social appearance. Since Weber, a large number of scholars have conducted research in this category. Social capital is not only the identity, resources and help that individuals receive through their social relationships and networks, but also the ability to access resources from social networks. Putnam (1995) defines social capital as "networks, norms and trusts that enable people to work together and pursue goals". Nahapiet and Ghoshal (1998) classify social capital into structural social capital, cognitive social capital, and relational social capital. This classification criterion is also used in the study to construct the model of the influence factors of occupational satisfaction from the perspective of social capital. Employee's structural social capital refers to the social network of employees in the enterprise, including social networks and social roles established through rules, procedures, and precedents. These networks promote the sharing of information among members, collective action, and the development of policies and rules that shape employee perceptions of the organization and influence employee occupational satisfaction. (Hu, 2011). In this study, the structural social capital is equated with the "organizational identity" dimension of the real estate B group employees, and the dimension is established in "overall satisfaction of the company", "internalization of corporate values", "work pride" "revenue satisfaction in the same industry", "company promotion mechanism identification", "company incentive mechanism identification" and "satisfaction of welfare treatment". These seven specific indicators are applied to assess the employee occupational satisfaction.

The employee's relational social capital covers trust and participation among members, value sharing, norms and punishments, obligations and expectations, etc. (Liao, 2012). In short, these factors will affect the mutual trust between members in the organization, and on the other hand affect the employee's satisfaction with the work. In this study, the cognitive social capital is equated with the "trust relationship (employee relationship) " dimension, and the dimension is established in " future career development", "leaders' emphasis on employees' work", "relationship with leaders", "relationship with colleagues", "performance recognition", "superior fairness" and "frequency of leadership care for employees". These seven specific indicators are applied to assess the employee occupational satisfaction.

The cognitive social capital of employees is mainly the members' self-awareness and planning in the relationship network. The employees' self-awareness is good, the career planning is clear, and the occupational satisfaction is higher (Liu, 2018; Li, etc. , 2017; Lu et al., 2017).This study is based on employees' research on their professional ability and matching, equating cognitive social capital with the dimension of "self-efficacy" and establishing this dimension in "learning and growing", "capable of exerting strengths", "performance evaluation", "matching of pay and reward", "satisfaction of daily workload", "work enthusiasm" and "job satisfaction". These seven specific indicators are applied to assess the employee occupational satisfaction.

On the basis of relevant literature research, the employee occupational satisfaction model from the perspective of social capital is constructed, as shown in Figure 1. Based on the previous research of social capital and the theoretical model of employee occupational satisfaction, if and only if all factors work together on the employee occupational satisfaction, the following assumptions are made:

H1: Organizational identity will have a positive impact on the employee occupational satisfaction.

H2: The trust relationship between employees will have a positive impact on the employee occupational satisfaction.

H3: Self-efficacy will have a positive impact on the employee occupational satisfaction. 


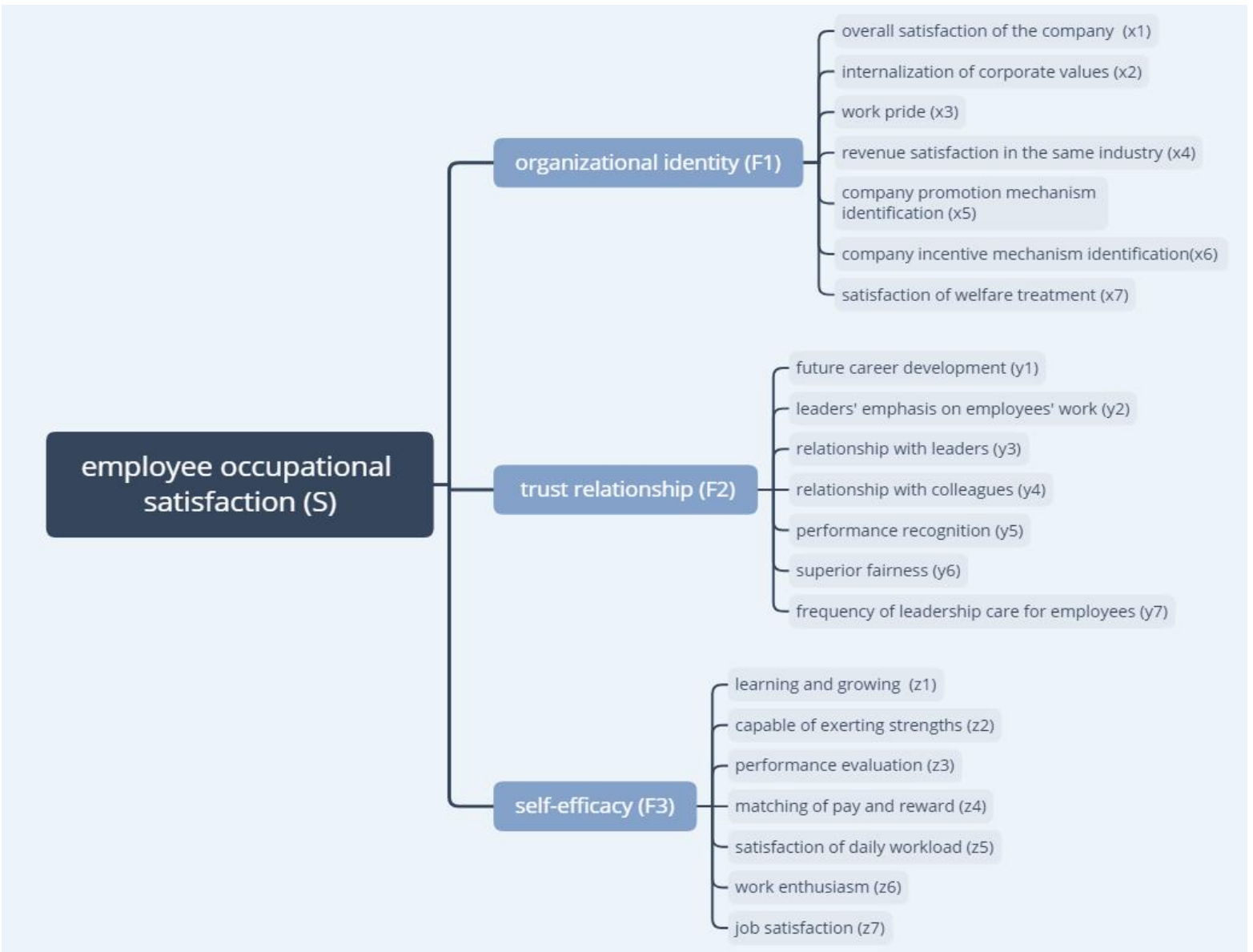

Figure 1. Model of employee occupational satisfaction model from the perspective of social capital

(Information source: made by author)

\section{Research Design}

According to the theory of social capital, and drawing on Nygard's Achievement Motivation Assessment Scale, It mainly studies the three dimensions of employee recognition of the organization (organizational identity), trust relationship among employees (employee relationship) and self-efficacy, using Likert's "five-point scale method" to measure the occupational satisfaction of employees of the real estate B Group G province branch, the research content covers indicators of employees' workplace education, job promotion, interpersonal relationships, value realization, performance appraisal, remuneration packages, etc. The participants in this survey included employees of various departments (regional platforms and sales centers) of the G branch of the real estate B group. Due to the large number of projects and the number of the branch, this survey uses a combination of quota sampling and random sampling. In this way, $20 \%$ of employees are selected in proportion in each department to complete the electronic questionnaire. When the respondents completed the questionnaire, we indicated the purpose and confidentiality of the questionnaire to the employees, ensured their right to informed consent, and established a trust relationship with the respondents. At the same time, in order to ensure the rigor and effectiveness of the research, the "mutual exclusion" questions were added to judge whether the employees' responses to the questionnaire were consistent and valid. For some questionnaires with obvious differences between the previous and the latter, these were treated as invalid questionnaires. The number of e-questionnaires was 600 , and a total of 547 copies of the questionnaire were retrieved from the data backstage. The recovery rate was $91.2 \%$, of which 538 were valid questionnaires, and the effective rate reached $97.8 \%$.

The data analysis software used in the research process is SPSS24.0, which can easily perform data cleaning, factor analysis and linear regression. The least squares method and the mean filling method are used to compensate for the lack of data or invalidity in the questionnaire. The least squares method is a data cleaning method for re-examining and correcting the data of this study. The main purpose is to delete the duplicate information in the data, correct the errors in the obtained data. The mean padding method is used to process 
invalid and missing values in the data to ensure consistency of the survey data. For the case where the partial variable options are inconsistent, the data is corrected by re-encoding and transposing the variables, and subsequent correlation analysis is performed.

Based on the Cronbach's Alpha value, the Cronbach's Alpha coefficient of each indicator directly used in the questionnaire was 0.882 , indicating that the scale has high reliability and high internal consistency. As shown in Table 1, according to the hypothesis, after extracting the principal factors, the KMO values of the principal factors of each dimension are greater than 0.75 , indicating that the construction validity of each dimension of the study is good, and it is suitable for the next analysis.

Table 1. KMO and Bartlett test for different dimensional factor analysis

\begin{tabular}{lllr}
\hline & KMO sampling suitability measure & & .763 \\
Organizational identity (F1) & Bartlett sphericity test & Approximate chi square & Degree of freedom \\
& & Significant & 977.165 \\
& & & .000 \\
\hline & KMO Sampling suitability measure & Approximate chi square & .779 \\
Trust relationship (F2) & Bartlett sphericity test & Degree of freedom & 1277.369 \\
& & Significant & 21 \\
& & & .000 \\
\hline & KMO Sampling suitability measure & .859 \\
& Bartlett sphericity test & Approximate chi square & 1252.785 \\
& & Degree of freedom & .000 \\
\hline
\end{tabular}

(Information source: author's survey data, processed by software SPSS 24.0)

\section{Factor Analysis and Linear Regression}

\subsection{Factor Analysis}

In the process of data analysis, the "organizational identity" dimension is built on seven specific indicators of "overall satisfaction with the company" (x1), "internalization of corporate values" (x2), "work pride" (x3), "revenue satisfaction in the same industry" (x4), "company promotion mechanism identification" (x5), "company incentive mechanism identification" (x6) and "satisfaction of welfare treatment" (x7), Using the SPSS 24.0 data analysis software, the seven indicator variables were extracted by the main factor, and then the "organizational identity" factor (F1) was obtained. In the principal factor analysis, we can get the expression of the factor F1 through the "component matrix", as follows:

\section{$F 1=0.64 X 1+0.703 X 2+0.671 X 3+0.673 X 4+0.717 X 5+0.767 X 6+0.199 X 7$}

The construction of the "trust relationship" dimension is based on seven specific indicators of "future career development" (y1), "leaders' emphasis on employees' work" (y2), "relationship with leaders" (y3), and "relationship with colleagues" (y4), "performance recognition" (y5), "superior fairness" (y6) and "frequency of leadership care for employees" (y7). Using SPSS 24.0 data analysis software, the seven indicator variables were extracted by principal factor, and then the "trust relationship" factor (F2) was obtained. In the principal factor analysis, we can get the expression of the factor $\mathrm{F} 2$ through the "component matrix", as follows:

\section{$F 2=0.631 Y 1+0.684 Y 2+0.485 Y 3+0.512 Y 4+0.796 Y 5+0.801 Y 6+0.641 Y 7$}

In the process of data analysis, the construction of the "self-efficacy" dimension is based on seven specific indicators of "learning and growing" (z1), "capable of exerting strengths" (z2), "performance evaluation" (z3), "matching of pay and reward" (z4), "satisfaction of daily workload" (z5), "work enthusiasm" (z6) and "job satisfaction" (z7). Using SPSS 24.0 data analysis software, the seven indicator variables were extracted by the main factor, and then the "self-efficacy" factor (F3) was obtained. In the principal factor analysis, we can get the expression of the factor F3 through the "component matrix", as follows:

\section{$F 3=0.533 Z 1+0.455 Z 2+0.654 Z 3+0.490 Z 4+0.374 Z 5+0.562 Z 6+0.248 Z 7$}

Correlation analysis of the factors F1, F2, and F3 with the "occupational satisfaction" indicator variables (see 
Table 2) results in the results of the hypothetical neutron hypothesis $\mathrm{H} 1, \mathrm{H} 2$, and $\mathrm{H} 3$.

Table 2. Correlation between different dimensional factors and occupational satisfaction

\begin{tabular}{|c|c|c|c|c|c|c|}
\hline & & $\begin{array}{c}\text { Career } \\
\text { satisfaction }\end{array}$ & Working years & F1 & F3 & F2 \\
\hline \multirow[t]{3}{*}{ Career satisfaction } & Pearson correlation & 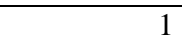 & -.011 & $.446^{* * *}$ & $.485^{* * *}$ & $.327^{* * *}$ \\
\hline & Significant (two-tailed) & & .801 & .000 & .000 & .000 \\
\hline & Number of cases & 538 & 538 & 538 & 538 & 538 \\
\hline \multirow[t]{3}{*}{ Working years } & Pearson correlation & -.011 & 1 & $-.089^{*}$ & -.043 & .009 \\
\hline & Significant (two-tailed) & .801 & & .039 & .315 & .839 \\
\hline & Number of cases & 538 & 538 & 538 & 538 & 538 \\
\hline \multirow[t]{3}{*}{$\overline{\mathrm{F} 1}$} & Pearson correlation & $.446^{* *}$ & $-.089^{*}$ & 1 & $.802^{* *}$ & $.745^{* *}$ \\
\hline & Significant (two-tailed) & .000 & .039 & & .000 & .000 \\
\hline & Number of cases & 538 & 538 & 538 & 538 & 538 \\
\hline \multirow[t]{3}{*}{$\overline{\mathrm{F} 3}$} & Pearson correlation & $.485^{* *}$ & -.043 & $.802^{* * *}$ & 1 & $.697^{* * 4}$ \\
\hline & Significant (two-tailed) & .000 & .315 & .000 & & .000 \\
\hline & Number of cases & 538 & 538 & 538 & 538 & 538 \\
\hline \multirow[t]{3}{*}{$\mathrm{F} 2$} & Pearson correlation & $.327^{* * 1}$ & .009 & $.745^{* *}$ & $.697^{* *}$ & 1 \\
\hline & Significant (two-tailed) & .000 & .839 & .000 & .000 & \\
\hline & Number of cases & 538 & 538 & 538 & 538 & 538 \\
\hline
\end{tabular}

** At the 0.01 level (two-tailed), the correlation is significant.

* At the 0.05 level (two-tailed), the correlation is significant.

(Information source: author's survey data, processed by software SPSS 24.0)

It can be seen from the correlation test results that there is no positive correlation between employee occupational satisfaction and working years, that is, the level of occupational satisfaction is not related to the working years; $\operatorname{sig}(\mathrm{F} 1)$ (significant value of $\mathrm{F} 1$ correlation analysis) $<0.05$, It is indicated that at a significant level of 0.01 , it can be concluded that there is a positive correlation between organizational identity and occupational satisfaction, that is, there is a positive correlation between organizational identity and employee occupational satisfaction at a probability of not less than $99 \%$; $\operatorname{sig}(\mathrm{F} 2)($ The significant value of F2 correlation analysis $)<0.05$, and it can be concluded that there is a positive correlation between trust relationship and occupational satisfaction, indicating that there is a positive correlation between the trust relationship and the occupational satisfaction, at a significant level of 0.01 , that is, improving the trust relationship of employees will effectively promote the improvement of employee occupational satisfaction; sig (F3) (significant value of F3 correlation analysis) $<0.05$, indicating that at a significant level of 0.01 , it is indicated that at a significant level of 0.01 , it can be concluded that there is a positive correlation between self-efficacy and occupational satisfaction, that is, there is a positive correlation between self-efficacy and occupational satisfaction at a probability of not less than $99 \%$, that is, improving employees' self-efficacy will be able to effectively promote employee occupational satisfaction.

\subsection{Linear Regression Analysis}

According to the descriptive statistics and correlation analysis results of each variable, this paper uses regression analysis to analyze the impact of each factor on employee occupational satisfaction. The organizational identity (F1), trust relationship (F2), and self-efficacy (F3) were used as independent variables, and regression analysis was performed with employee occupational satisfaction (S) to obtain the results. After verification, it is found that the trust relationship $(\mathrm{F} 2)$ has a significant value $(\mathrm{t}(\mathrm{F} 2)=0.089)$ greater than 0.05 in the regression coefficient test. Through further data adjustment, the factor F2 and the dependent variable S are directly linearly regressed to obtain the modified model 2. It is found that there is linear correlation between F2 and the dependent variable S. Then we do the collinear analysis of the variables of the component factor F2, and take each variable as a separate independent variable, participating in the factors F1, F2 and the dependent variable S, and finally screening out the inappropriate variables (Y3, Y4, Y5, Y6). The variables Y1, Y2, and Y7 are re-analyzed by factor analysis to obtain the factor F2', (KMO value is 0.678 ). We incorporated F2', into the modified model 3, as shown in the following table: 
Table 3. Model Summary and ANOVA Test

\begin{tabular}{lccccc}
\hline & & & & Standard estimated & ANOVA saliency \\
& model & $\mathrm{R}$ & R square & Adjusted R square & error \\
\hline 1 & $0.499^{\mathrm{a}}$ & 0.249 & 0.245 & 1.089 & $0.00^{\mathrm{b}}$ \\
2 & $0.327^{\mathrm{a}}$ & 0.107 & 0.105 & 1.185 & $0.00^{\mathrm{b}}$ \\
3 & $0.513^{\mathrm{a}}$ & 0.263 & 0.259 & 1.078 & $0.00^{\mathrm{b}}$ \\
\hline
\end{tabular}

Model 1: a. Dependent variable: $\mathrm{S}$

b. Predictors: (constant), F3, F2, F1

Model 2: a. Dependent variable: $\mathrm{S}$

b. Predictor: (constant), F2

Model 3: a. Dependent variable: $S$

b. Predictors: (constant), F3, F2', F1

(Information source: author's survey data, processed by software SPSS 24.0)

Through linear regression and correction, the $\mathrm{F}$ values in the ANOVA analysis are the fits of the regression equations. The $\mathrm{F}$ values of the three models are 58.532, 64.04, 63.63, and the significant values are 0 . It shows that the regression equations of the three models are significant and the results are good, which can reflect the linear correlation between factors and dependent variable.

Table 4. Model 1, Model 2, Model 3 Regression Coefficient Table ${ }^{\text {ab }}$

\begin{tabular}{|c|c|c|c|c|c|c|}
\hline \multirow[b]{2}{*}{ model } & & \multicolumn{2}{|c|}{$\begin{array}{c}\text { Unnormalized } \\
\text { coefficient }\end{array}$} & $\begin{array}{c}\text { Standardization } \\
\text { coefficient }\end{array}$ & \multirow[b]{2}{*}{$\mathrm{t}$} & \multirow[b]{2}{*}{ Significant } \\
\hline & & $\mathrm{B}$ & $\begin{array}{l}\text { Standard } \\
\text { error }\end{array}$ & Beta & & \\
\hline \multirow[t]{4}{*}{1} & (constant) & 4.028 & .047 & & 85.812 & .000 \\
\hline & $\mathrm{F} 1$ & .265 & .087 & .211 & 3.031 & .003 \\
\hline & $\mathrm{F} 2$ & -.124 & .073 & -.099 & -1.702 & .089 \\
\hline & F3 & .482 & .081 & .385 & 5.932 & .000 \\
\hline \multirow[t]{2}{*}{2} & (constant) & 4.028 & .051 & & 78.841 & .000 \\
\hline & $\mathrm{F} 2$ & .409 & .051 & .327 & 8.003 & .000 \\
\hline \multirow[t]{4}{*}{3} & (constant) & 4.028 & .046 & & 86.656 & .000 \\
\hline & F1 & .292 & .144 & .146 & 2.339 & .020 \\
\hline & $\mathrm{F} 2{ }^{\prime}$ & .232 & .63 & .185 & 3.675 & .000 \\
\hline & F3 & .558 & .121 & .244 & 3.513 & .000 \\
\hline
\end{tabular}

Model 1: a. Dependent variable: $\mathrm{S}$

b. Predictors: (constant), F3, F2, F1

Model 2: a. Dependent variable: $\mathrm{S}$

b. Predictor: (constant), F2

Model 3: a. Dependent variable: $\mathrm{S}$

b Predictors: (constant), F3, F2', F1

(Information source: author's survey data, processed by software SPSS 24.0)

According to the model 3 with higher level of significance in the regression coefficient table, the linear regression equation model of occupational satisfaction $(\mathrm{S})$ and organizational identity (F1), trust relationship (F2'), and self-efficacy (F3) is finally obtained:

$$
\mathrm{S}=0.146 \mathrm{~F} 1+0.185 \mathrm{~F} 2+0.244 \mathrm{~F} 3
$$

Through further interpretation of the equation, self-efficacy (F3) has the greatest effect on occupational 
satisfaction in the change of employee occupational satisfaction (S), followed by trust relationship (F2') and organizational identity (F1).From the change of the "trust relationship" factor adjustment process, it can be considered that in the real estate enterprise, "relationship with leaders", "relationship with colleagues", "superior fairness", and "performance recognition" are not significantly related to the improvement of occupational satisfaction. The reason for this conclusion is that real estate enterprises have formed a scientific management system as a business entity with relatively complete development and sound organizational structure. The relationship between employees and employers is no longer a simple personal and dependent relationship. The importance of organizational identity is higher than the importance of the relationship between the upper and lower levels and colleagues. The evaluation of performance is also scientifically and comprehensively considered by the human resources department of the enterprise, rather than being directly unilaterally led by the superior leadership. On the other hand, in real estate enterprises that highlight individual performance, the importance of the relationship between the superior and the subordinates is weakened and giving more space to employees, which is conducive to employees to further develop their positional creativity, more prominent personal achievements and performance, so the support between colleagues is relatively weak.

\section{Discussion and Summary}

According to the analysis results, the three hypotheses proposed in this study, H1, H2, and H3, are all established, that is, "organizational identity", "trust relationship", and "self-efficacy" will have a positive impact on employee occupational satisfaction. By analyzing the factors of three dimensions and linear regression, it is found that "self-efficacy" has the greatest effect on occupational satisfaction, followed by "trust relationship" and "organizational identity". For the change of variables in the process of adjusting the relationship of trust factors, it can be considered that in real estate enterprises, "relationship with superiors", "relationship with colleagues", "superior fairness", and "performance recognition" are not significantly related to the improvement of employee occupational satisfaction. Through the linear regression model, the conclusion is drawn: First, there is a linear correlation between employee occupational satisfaction (S) and organizational identity (F1), trust relationship (F2), and self-efficacy (F3). Second, compared with organizational identity (F1) and self-efficacy (F3), the trust relationship (F2) is low in significance, and the linear correlation with employee occupational satisfaction (S) is relatively weak, that is, when three factors simultaneously act on occupational satisfaction, trust relationship (F2) is less important than organizational identity (F1) and self-efficacy (F3).

The research conclusions show that in the three dimensions of "organizational identity", "trust relationship" and "self-efficacy", the most important factor influence on employee occupational satisfaction is "self-efficacy". The "exit-call-loyalty" theory can help to understand this perception of real estate employees. The decision to choose "exit" or utter ("call") will depend on one's loyalty to the organization. In the organization, higher loyalty will result in one choosing to utter ("call") instead of exiting (Fu, 2011). Real estate enterprises should pay attention to the cultivation of employees' "organizational identity". The company's promotion system and welfare compensation system will directly affect employees' perceptions of pay and return, and thus affect employees' occupational satisfaction. Therefore, enterprises should continually promote a more scientific management system, and pay more attention to employees' perceptions of promotion mechanisms and welfare treatment. Real estate companies should also focus on stimulating employees' "calls", that is, paying attention to employees' sense of satisfaction in their work, improving their self-efficacy through improving the incentive system, enhancing employees' organizational enthusiasm and work enthusiasm, enabling employees to develop their talents, retaining outstanding talents for the enterprises, and reducing recruitment and training costs.

In terms of trust relationship among employees, the company can reduce the attention of employees in terms of "relationship with leaders", "relationship with colleagues", "performance recognition" and "superior fairness", and turn to "future career development", "leaders' emphasis on employees' work" and "the frequency of leadership care for employees". In order to build a harmonious labor-management relationship, in addition to paying attention to the work status and efficiency of employees, we must also pay attention to the psychological state of employees. (Wang, 2018). It is indispensable to pay attention to the work of employees in the enterprise, but employees may tend to form a kind of cognition in the workplace observation: the care of the leader is regarded as "supervision of their work", which is a kind of vertical work pressure, a signal of change in workplace status and workplace identity. It is also the main representation of workplace anxiety, which will directly affect the work efficiency of employees. Therefore, in terms of the trust dimension of employees, companies should pay attention to the frequency of employee care, and care too often may lead to a decline in employee occupational satisfaction.

In terms of organizational identity, although this dimension has less influence on employee occupational satisfaction than "self-efficacy", in some indicators, enterprises should also pay attention to and adjust. On one 
hand, modern employees are paying more attention to self-improvement and the ratio of labor and compensation. More and more workers leave because of the company's lack of promotion and dissatisfaction with the company's system. (Yuan\&Qian, 2017). For employees, the organization's culture, values, and pride in work are not the main factors that determine whether an employee is staying in a company, but the company's systems and benefits will directly affect employees' perceptions of pay and reward, which in turn affects employee occupational satisfaction, so companies should pay more attention to employees' feelings about organizational promotion mechanism, incentive mechanism and welfare treatment. On the other hand, dealing with interpersonal relationships requires a certain amount of energy, especially when dealing with interpersonal relationships based on job roles. Emotion is also one of the important reasons that affect employee's career satisfaction (Wang\&Gao, 2017). In the maintenance of the relationship with the leader, it is necessary to invest more energy, but also need to consider other factors, such as the company system, internalization of values, etc. This change in relationship will lead to role tension and cognitive conflict, which in turn affects employee occupational satisfaction perception and work mood, and makes employees feel negative and slack. Therefore, companies should pay attention to the employees' work mood, promptly guide and encourage, reduce the role tension and eliminate the cognitive conflicts of employees.

While improving the occupational satisfaction of employees, real estate enterprises should also pay attention to the boundary problem of "organizing the public domain" and "employee private domain" to prevent the decline of employee occupational satisfaction due to management method. For example, leaders' emphasis on employees' work is indispensable, but employees tend to form a kind of cognition in the workplace observation: the care of leaders or supervisors is regarded as "supervising their own work". This is a vertical work pressure, a signal of change in workplace status and workplace identity. It is also a major indicator of workplace anxiety and will directly affect employee productivity. Therefore, real estate companies should pay attention to the frequency of employee care and avoid the decline of employee occupational satisfaction due to too frequent care; on the other hand, dealing with interpersonal relationships requires a certain amount of energy, especially dealing with relationships based on job roles. Employees need to invest in the maintenance of their relationship with their superiors and colleagues. They also need to consider other factors, such as company system and internalization of values, etc. Such change in relationship can lead to role tension and cognitive conflicts, which in turn affects employee occupational satisfaction perception and work mood, and causes employees feel negative and slack. Therefore, companies should pay attention to the employee's work mood, take various measures to reduce internal informal social relations that may affect organizational identity, and eliminate employee role tension and cognitive conflict.

\section{References}

Dirianzani, L., Sugiono, S., \& Hardiningtyas, D. (2014). Analisis pengaruh motivasi intrinsik dan ekstrinsik terhadap kinerja karyawan borongan dengan komitmen organisasi sebagai mediasi (studi kasus: Perusahaan Rokok Adi Bungsu Malang). Jurnal Rekayasa dan Manajemen Sistem Industri, 2(5), 1124-1135.

Fathoni, A. O. (2006). Manajemen Sumber Daya Manusia [M]. Jakarta: Rineka Cipta.

Fu, F. (2011). The Enlightenment of the Theory of Exit, Appeal and Loyalty on the Study of Resignation. Economic Research Guide, 35, 212-214.

Hoppock, R. (1935). Job satisfaction. New York, NY: Harper \& Brother Publisher.

Hu, D. F. (2011). The Structure and Measurement of Rural Social Capital_-An Empirical Study of Putnam's Social Capital Theory. Journal of Wuhan University (Philosophy and Social Sciences), 4, 62-68.

Li, C. L., Liu, S. L., \& Zhu, L. (2017). Research on the Impact of International R\&D Alliance Network Structure on Enterprise Innovation Performance-Based on Social Capital Perspective. Science and Technology Management, 1, 54-63.

Liao, Y. H. (2012). The Influence of Internal Social Capital on the Satisfaction of Members of Farmer Cooperatives: Moderating Role of the Level of Standardization of Management. Comparison of Economic and Social Systems, 5, 169-182.

Liu, Q. (2018). Discussion on the Theory and Method of Social Capital Measurement: Measurement of Farmers' Social Capital. Journal of Finance and Economics, 4, 122-130.

Lu, S. H., Yao, Y. T., \& Wang, H. (2017). How do Social Capital Influence Rural Households' Life after Land Acquisition: An Empirical Analysis based on Ordered Logistic Model. China Land Science, 6, 3-12.

Nahapiet, J., \& Ghoshal, S. (1998). Social capital, intellectual capital, and the organizational advantage. 
Academy of Management Review, 23(2), 242-266. https://doi.org/10.5465/amr.1998.533225.

Lan, N. (2007). Refined understanding of perspectives on employee-organization relationships. Journal of Communication Management, 11(1), 53-70. https://doi.org/10.1108/13632540710725987

Putnam, R. D. (1995). Tuning in, tuning out: the strange disappearance of social capital in America. Ps Political Science \& Politics, 28(4), 664-683. https://doi.org/10.2307/420517.

Wang, H. X. (2018). How to build a harmonious enterprise-employee relationship. People's Forum, 20 , 88-89.

Wang, L., Gao, Y. J., \& Zhang, X. Y. (2017). Predictors of Emotional Creativity and the Relationship between Emotional Creativity and Coping Style. Psychological Science, 5, 1168-1174. https://doi.org/10.16719/j.cnki.1671-6981.20170522.

Wang, Y. G. (2018). Research on the Relationship between High Performance Work System and Job Satisfaction. Technology Economics and Management Research, 2, 32-36

Yuan, Q. H., Qian, S. S., \& Wang, C. Y. (2017). The Review and Prospect for Employee Turnover Research. China Human Resources Development, 4, 6-14. https://doi.org/10.16471/j.cnki.11-2822/c.2017.04.003.

\section{Copyrights}

Copyright for this article is retained by the author(s), with first publication rights granted to the journal.

This is an open-access article distributed under the terms and conditions of the Creative Commons Attribution license (http://creativecommons.org/licenses/by/4.0/). 